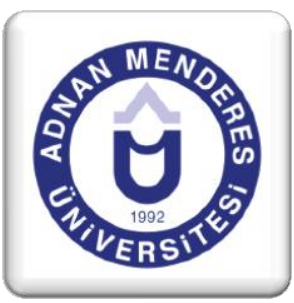

\title{
Pazarlama İletişim Sürecinde Örtü Kullanımı: Üniversite Öğrencileri Üzerinde Bir Uygulama ${ }^{1}$
}

\author{
Başar ALTUNTAŞ ${ }^{2}$, M. Şükrü AKDOĞAN ${ }^{3}$
}

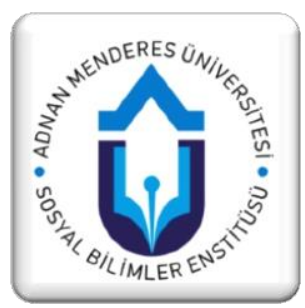

\section{ÖZET}

Son birkaç yüzyıldan beri sosyo-ekonomik ve teknoloji alanlarında meydana gelen değişimler günümüzde farklı bir tüketici yapısının oluşmasına neden olmuştur. Geçmişin başarılı olan stratejilerinin yeni tüketici yapısıyla iletişim kurabilmek için yeterli olmadığı görülmüş ve etkinliği tartışılır hale gelmiştir. Bu sorunun üstesinden gelebilmek için pazarlamacılar, işletmelerin uygulayabileceği yeni ve alternatif yöntemler geliştirmeye çalışmaktadırlar. Örtülü pazarlama son dönemlerde ortaya çıkan ve firmaların iletişim problemine çözüm üretebilecek alternatif bir strateji olarak görülmektedir.

$\mathrm{Bu}$ çalışmanın amacı pazarlama iletişim sürecinde örtü kullanılmasının etkisini tespit etmek ve demografik özelliklerine göre tüketicilerin tutumu ile uygulanan örtülü tekniğin etkinliğini değerlendirmeleri arasında farklılık olup olmadığını ortaya koymaktır. Elde edilen sonuçlara göre tüketiciyle iletişim sürecinde gerçek kaynak (firma) üzerinde kullanılan örtü seviyesinin tüketici tutumu ve tekniğin etkinliğini değerlendirmeleri üzerinde etkisinin olduğu tespit edilmiştir. Mesaj üzerinde kullanılan örtünün herhangi bir etkisinin olmadığı görülmüştür. Ayrıca kişilerin etiksel algılamalarının örtü seviyesinden etkilenmediği, kadınların erkeklere göre örtülü pazarlamaya karşı daha hassas oldukları, sağlık alanında eğitim gören kişilerin teknik ve sosyal ağırlıklı eğitim görenlere kıyasla örtü kullanılmasına karşı daha olumsuz tutum ve değerlendirme içerisinde oldukları sonucuna ulaşı1mıștır.

Anahtar Kelimeler: Örtülü pazarlama, iletişim, strateji, postmodern

\section{Using Cover in Marketing Communication Process: A Case Study on College Students}

\begin{abstract}
Socio-economic and technological changes occurring since the last few centuries have caused a different formation of today's consumers than the past. It was observed that the successful strategies of the past is not enough to communicate with the new consumers and the effectiveness of the strategies have become questionable. Marketers are trying to develop new and alternative methods to overcome with this problem. Covert marketing has emerged in recent years and it is seen as a solution to the communication problem of firms.
\end{abstract}

The aim of this study is to determine the effect of using cover in marketing communication process and to reveal whether differences between consumers' attitudes and evaluation the effectiveness of covert techniques in terms of demographic characteristics. According to the results, it has determined that using a cover on the real source (company) while in the process of communication with the consumer has an affect on the attitude of consumer and the evolution of applied techniques effectiveness. Using cover on message has not proved any effect. Also it concluded that consumers' ethical perceptions have not affected by the level of cover, women are more vulnerable than men to the covert marketing and people whom are trained in the field of health have more negative responses and attitudes towards covert marketing than people studying technical and social fields.

Keywords: Covert marketing, communication, strategy, postmodern

\footnotetext{
${ }^{1}$ Bu çalışma, Nevşehir Hacı Bektaş Veli Üniversitesi Sosyal Bilimler Enstitüsü İşletme Anabilim Dalı Doktora öğrencisi Başar ALTUNTAŞ tarafından Prof. Dr. M. Şükrü AKDOĞAN danışmanlığında tamamlanan "Örtülü Pazarlama Stratejisi: Stratejiye Bağlı Olarak Tüketici Tutumunun ve Uygulanan Tekniğin Etkinliğinin Araştırılması" adlı doktora tezinden türetilmiştir.

${ }^{2}$ Yrd.Doç.Dr., Ahi Evran Üniversitesi, Ziraat Fakültesi, Tarım Ekonomisi Bölümü.

${ }^{3}$ Prof. Dr. M., Erciyes Üniversitesi, İktisadi ve İdari Bilimler Fakültesi, Üretim Yönetimi ve Pazarlama Abd.
} 


\section{Giriş}

Pazarlama bilimi ortaya çıkışından günümüze kadar gelen süreçte içinde bulunduğu dönemin toplumsal ve teknolojik şartlarına uygun olarak gelişmesini sürdürmüştür. $\mathrm{Bu}$ süreç içerisinde özellikle İkinci Dünya Savaşı sonrasına denk gelen 1950'li yıllar önemli gelişmelerin yaşandığı bir dönem olmuştur. Toplumların gelirlerinin artmaya başlaması, eğitim seviyesinin hızla yükselmesi, bilimsel çalışmaların yoğunlaşması, ulaşım imkânlarının gelişmesi ve kültürler arası etkileşimin artması, bu gelişmelerin temel etkenleri olmuştur. Modern pazarlama anlayışının filizlendiği bu dönemde yeni eğilimleri ifade etmek için sanat ve mimari başta olmak üzere birçok alanda postmodern kavramı kullanılmaya başlanmıştır. Yeni kavramın pazarlama disiplinince ve tüketici nezdinde kabul görmesi 1980'li yılların sonlarına rastlamaktadır (Odabaşı ve Kılıçer, 2010:31) ve bundan sonrasında pazarlama alanında postmodernizmin etkileri derinden görülmeye başlamıştır. Postmodern dönemin şartları ve duyarlılıkları, modern döneme ait tüketim ve tüketici anlayışını değiştirmiştir. Modern pazarlamaya göre tüketici bilinçli ve satın alma iradesi olan aydınlatılmış kimselerdir ve tüketicilerin davranışları sosyal sınıf, kültür, demografik özellikler gibi geleneksel bir takım değişkenlerle açıklanabilmektedir (Burton, 2002:792). Postmodern anlayışa göre ise tüketici günlük mutluluk peşinde koşan, anında tatmin isteyen, ihtiyaçlarını ertelemeyen ve gelecek için bugünü feda etme niyetinde olmayan, geçmiş ve geleceği içerecek biçimde denemeyi büyük bir arzuyla isteyen, içerik yerine biçime daha çok ilgi duyabilen, hazcı yönü öne çıkan ve kendisini tüketime hazır bir imaj haline getirmiş kimselerdir (Odabaşı, 2009:65). Bu kişiler sık sık karar değiştiren, marka sadakati zayıf, anlık satın almalara göre hareket eden, alışveriş deneyimine daha fazla değer veren bir yapıdadır (Babacan ve Onat, 2002:14). Sürekli bugünü yaşamak isteyen postmodern tüketici şekil ve biçime önem vermekte, düzensizlik ve kaosu kabul etmektedir (Brown, 1993). Tüketim eylemini fizyolojik ihtiyaçlarının yanı sıra psikolojik ve sosyolojik ihtiyaçlarını karşılamaya yönelik bir eylem olarak değerlendirmektedirler. Parçalanmış, çeşitlenmiş, farklılaşmış ve karmaşık hale gelmiş yeni nesil tüketici kitlesine tek ses, tek görüş, tutarlılık ve eşgüdüm gibi kavramlar ile ulaşmaya çalışmak firmalara ancak ve ancak sınırlı yarar sağlayabilmektedir. Bu kitleye yönelik bütünleşik bir uygulama kızgınlık yaratabileceği gibi pazar sunumuna da ilgiyi azaltabilecektir (Odabaşı ve Kilıçer, 2010: 42). Bu nedenle içinde bulunulan dönemin dinamiklerini anlamak ve bu doğrultuda pazarlama stratejilerine yön vermek firmalar açısından kaçınılmaz hale gelmektedir (Azizağaoğlu ve Altunışık, 2012:44). Son yıllarda ortaya çıkan gerilla, izinli, deneyimsel, veri tabanı, etkinlik ve örtülü pazarlama gibi birçok strateji değişen bu yapıya uyum sağlayabilme arayışının bir sonucu olarak görülmektedir.

Örtülü pazarlama konusuna odaklanan bu çalışmanın temel amacı pazarlama iletişim sürecinde gerçek kaynak ve mesaj üzerinde kullanılan örtü seviyesine yönelik tüketici tutumunu ve uygulanan örtülü tekniğin etkinliğini tespit etmektir. Ayrıca demografik özelliklerine göre tüketiciler arasında tutum ve tekniğin etkinliğini değerlendirmelerinde farklılık olup olmadığını ortaya koymak bir diğer amaçtır. Literatürde konuyla ilgili yapılan çalışmalar (Ahmed, 2000; Kaikati ve Kaikati, 2004; Petty ve Andrews, 2008; Roy ve Chattopadhyay, 2008; Milne, Bahl ve Rohm, 2008; Campbell vd., 2013) stratejinin teorik altyapısını oluşturmalarının yanı sıra örtülü teknikleri sınıflandırmaya ve etiksel boyutunu değerlendirmeye yönelik yürütmüşlerdir. Bu çalışma ise örtülü pazarlama stratejisini hem teorik hem de uygulamalı olarak ele almaktadır. Bununla birlikte firmalar tarafindan rekabette kullanılan birçok pazarlama tekniğini, örtülü pazarlama stratejisi kapsamına dahil etmekte ve açıklamaktadır. Bu yönleriyle diğer araştırmalardan farklılaşan çalışmanın yerli 
alanyazınına katkısının olacağı öngörülmektedir. Ayrıca çalışma sonuçları pazarlamacıların tutundurma faaliyetlerine yön verebilecek niteliktedir.

\section{2.Örtülü Pazarlama Stratejisi}

Tüketici dünyasında insanlar, pazarlama mekanizmasının hiçbir şeyinden habersiz kişileri değillerdir. İnsan yaşamı, şimdiye kadar benzeri görülmemiş biçimde ticari mesajlarla tanımını bulmaktadır (Solomon, 2003:58). İçinde bulunulan zaman tüketicilerin reklamlardan, haberlere kadar geniş yelpazede tam bir iletişim bombardımanına tutulduğu bir çağdır. $\mathrm{Bu}$ bombardıman izlenilen programlardan katılınan etkinliklere kadar yayılmaktadır hatta Weisberg, Pfleiger ve Friedberg (2007:1)'nin de belirttiği gibi oynanılan oyunlardan uzaya gönderilen uyduya kadar birçok alanda firmaların izine rastlayabilmek mümkündür. Tüketiciler günün ilk saatlerinden gece vakitlerine kadar, sürekli olarak kendilerini ikna etmeye çabalayan birçok mesaja maruz kalmaktadırlar. Meydana gelen mesaj krizini ifade etmek için araştırmacılar (Silverman, 2006:40; Kirby ve Marsden, 2006:201; Borça, 2007:111), dünya genelinde ortalama bir tüketicinin günlük olarak 200 ile 5000 arasında değişen mesaja maruz kaldığını ifade etmektedirler. Ancak bu mesajlardan çok az bir kısmı bilinçli olarak algılanmakta ve bunlarında çok az bir kısmı kişileri alışveriş yapmak üzere mağazaya sürükleyebilmektedir (Jurca, 2010:323; Pringle, 2007:98). Bu mesaj yığınları içerisinde potansiyel tüketicilerin dikkatini çekebilmek fazlasıyla zorlaşmışıı (Swanepoel vd., 2009:9). Mesaj yığınlarının oluşmasında önemli etkenlerden biri televizyon ve radyo kanal sayısının artmış olmasıdır. Bu durum mevcut tüketicilerin çok fazla parçalanmasına ve küçük gruplara bölünmesine de sebep olmuştur (Kaikati ve Kaikati, 2004:8). Artık tüketicinin kitleselliğinin yerini, bireysellik almıştır. Haliyle geleneksel reklamcılığın etkinliği tartışmalı hale gelmiştir. Günümüzün etkili kitle iletişim ortamlarından biri olarak kabul edilen televizyon kanallarında, 15-30 saniye aralığında gösterilen reklamın tüketiciye ulaşabilmesi kolay değildir (Akdoğan ve Altuntaş, 2015a:279). Ayrıca kısa süreli reklam filmlerinin kitle iletişim araçlarında gösterim maliyetlerinin yükselmesi etkinlik sorununu kendisiyle birlikte getirmiştir.

Mevcut durumun güçlüğü yalnızca bununla sınırlı değildir. Tüketicinin geçmişe kıyasla daha bilinçli davranması ve teknolojiyle olan barışıklığı işleri daha karmaşık hale getirmektedir. Mesajlara karşı dikkatini vermemeye çalışan tüketici, mesajları engelleyebilmekte ya da onlardan kaçınabilmektedir (Petty ve Andrews, 2008). Firmalar ise hedef tüketicisiyle etkileşime geçilebilmek için uygun buldukları her mekâna (okul, işyeri, kafe, sokak, cami vb.) mesajını konuşlandırmaya devam etmektedir. Ancak firmaların yoğun girişimleriyle sürdürülen tüketiciyi etki altına alma çabası zamanla tüketicinin mesajlara karşı bağışıklık kazanmasına neden olmuştur (Jurca, 2010:323). Zaten mesaja karş1 ilgisiz olan tüketici bunun sonucunda tamamen duyarsız hale gelmiştir (Gupta ve Lord, 1998). Bununla birlikte tüketicilerin elinde bulunan bir diğer avantaj ise teknolojik alanda yaşanılan gelişmelerdir. Geliştirilen aygıtlar sayesinde tüketici mesajdan kaçabilmektedir. Geleneksel reklamcıllı̆ı önemli ölçüde etkileyen bu aygitlar dijital ve kişisel video kaydediciler (DVR ve PVR) olarak adlandırılmaktadır. Bunları kullanan izleyiciler, programları kaydedebilmekte ve reklam kuşaklarını atlayabilmektedirler (Kaikati ve Kaikati, 2004; Swanepoel vd.,2009:10). Ayrica arama yapma kayıtları ile arayan kimlik sistemleri sayesinde tele marketing aramalarını; sanal ortamdaki koruma programlarını kullanarak da internet ve mobil mesajları engelleyebilmeleri mümkün hale gelmiştir. Böylelikle tüketiciler hem ticari mesajlardan uzak durabilmekte (Martin ve Smith, 2008:46) hem de bu mesajları kontrolü altında tutabilmektedirler. Firmalar bu olumsuz tablo içerisinde tüketicinin dikkatini çekebilmeyi ve tercihleri hakkında bilgi toplayabilmeyi başarmaları halinde rekabette avantaj sağlayabileceklerdir (Milne vd., 2008:57). Firmaların hedef tüketicilerine ulaşabilmeleri için 
geleneksel yöntemlerin dışında zamanın dinamiklerine uygun yeni çözüm yolları bulmaları halinde, bu avantajı elde edebileceklerdir.

Örtülü pazarlama içinde bulunduğumuz dönemde firmaların karşısında alternatif çözüm olarak duran bir stratejidir. Bu strateji pazarlama iletişiminin pazarlama iletişimi gibi görünmediği uygulamalardan oluşmaktadır ve bu iletişimde ticari kaynak, ticari mesaj ayrı ayr1 maskelenebileceği gibi her ikisi birden de maskelenebilmektedir (Petty ve Andrews, 2008:7). Örtülü pazarlama stratejisi birçok araştırmacı (Kaikati ve Kaikati, 2004; Scanlon ve Hearn, 2006; Petty ve Andrews, 2008; Roy ve Chattopadhyay, 2010; Martin ve Smith, 2008; Milne vd., 2008; Swanepoel vd., 2009) tarafından farklı şekillerde tanımlanmıştır. Bütün tanımlamaların özünde, tüketici ile iletişime geçme esnasında firmanın ve mesajın ya da her ikisinin ayrı ayrı üzerinin örtülerek, mesajın alıcıya ulaştırılmasından bahsedilmektedir. Böylece alıcının mesajdan kaçınmasının önüne geçilmekte ve mesaj kendisine ulaştırılabilmektedir. Mesaja maruz kaldığını fark etmeyen tüketicinin gelecekteki satın almaları için alt yapı oluşturulmakta ve ürünle ilgili olumlu ağızdan ağıza yayılımın başlama olasılığı ortaya çıkmaktadır. $O$ halde örtülü pazarlama stratejisini, pazarlama iletişim sürecinde gerçek kaynağın ve/veya iletilecek olan mesajın üzerinde belirli seviyelerde örtü kullanılarak, alıcı ile etkileşime geçilebilecek her türlü ortamda mesajın aktaran kaynak tarafından alıcıya iletilmesi süreci olarak tanımlayabiliriz.

Örtülü pazarlama stratejisi son yıllarda daha fazla ele alınmaya başlanmış olsa da stratejinin uygulama tekniklerine geçmiş yıllarda rastlayabilmek mümkündür. Bilinen en eski örtülü pazarlama uygulamas1 17-18. yüzyıl İngiltere'sinde tiyatro izleyicilerinin arasına yerleştirilen insanların, oyun sonunda ayağa kalkıp, "bravo" diye bağırmaları için para karşıllı̆ı tutulmalarıdır (Taylor, 2003). Böylece izleyenler üzerinde oyundan etkilenildiği ve oyunun beğenildiği havası yaratılmıştır. Yine 1920'li yıllarda Macy's departmanlı mağazaları elinde kalan uzun beyaz eldivenler için 25 güzel giyimli kadını işe almış ve bu eldivenleri kollarına takarak, yoğun metro istasyonlarında dolaşmaları istenilmiştir. Sonucunda elde kalan ve satılamayan bu eldivenler birkaç hafta içerisinde tamamen satılabilmiştir (Kaikati ve Kaikati, 2004:11). Örtülü pazarlama stratejisinin yaratıcısının Amerikalı Edward Barneys olduğunu iddia eden Canşen (2011), Barneys'in 1929 y1lındaki Lucky Strike sigaraları için hazırlamış olduğu kampanyanın örtü stratejisinin başarılı örnekleri arasında yer aldığını belirtmektedir. Kadınların sigara içmede özgür olabileceklerine yönelik yürütülen kampanyada, New York'ta düzenlenen geleneksel Paskalya yürüyüşü esnasında Barneys tarafından örgütlenen bir grup feminist, ince çorapları içerisinden çıkartmış oldukları sigaraları yakmışlar ve erkekler ile eşit olduklarını ispatlamaya çalışmışlardır. Kadınların bu geçişi yine Barneys tarafından örgütlenen gazeteler tarafindan ilk sayfa haberlerine taşınarak Lucky Strike markasını uzun vadede başarıya ulaştırmıştır. Stratejinin bilimsel olarak ele alınması Vance Packard'ın 1957 yılında yayınlanan "The Hidden Persuaders" adlı kitabıyla başlamıştır (Roy ve Chattopadhyay, 2010: 70). Konuya uzun süre ilgisiz kalan araştırmacıların 1990'lı yıllarla birlikte stratejiye tekrar dikkat çektikleri ve 1994 yllında Balasubramanian'ın yayınlanan makalesinin stratejiye olan ilgiyi arttırdığ 1 görülmektedir. Makalesinde firma tarafından hazırlanan ticari mesaj üzerine odaklanan Balasubramanian, farklı iki pazarlama iletişim uygulamasının (reklam ve tanıtım) avantajlı özelliklerinin bir araya getirilmesiyle oluşturulacak mesajın, tüketici tarafindan kabul edileceğini iddia etmiştir. Bu çalışma sonrasında firmanın kimliği ifşa edilmeden, mesajın iletilebileceği fikri yaygınlaşmaya başlamıştır. Sonraki yıllarda hem bilim adamları hem de pazarlama uygulayıcıları ile araştırmacı gazetecilerin stratejinin gelişmesine katkı sağlayacak makale, köşe yazısı (Leon, 2004; Rutenberg, 2001) ve deneme yazısı (Carlson, 2004) yayınladıkları görülmektedir. Stratejinin kavramsallaştırılmasında ve 
akademik camia ile tanıștırılmasında Kaikati ve Kaikati (2004) tarafından yayınlanan kuramsal makalenin önemli bir yeri bulunmaktadır. Tüketicinin farkında olmadan ona ulaşma yöntemlerini anlattıkları makalede, stratejinin güçlü ve zayıf yönleri, etiksel kaygıları ve diğer kesimlerce yöneltilen eleştiriler ele alınmış ve stratejinin geleceği tartışılmaya başlanmıştır. Takip eden yıllarda Roy ve Chattopadhyay (2008) örtülü pazarlama stratejisinin pazarlama karması elemanlarında kullanılabileceğini göstermişlerdir. Aynı yıl Milne, Bahl ve Rohm (2008) stratejinin, sanal ortamda uygulanabileceğini belirterek, stratejiyi farklı bir alana taşımışlardır. Stratejiyi şüphecilik ve ikna bilgisi çerçevesinde ele alan Martin ve Smith (2008) ise stratejinin etiksel boyutlarını tanımlayarak, analiz etmişlerdir. Farklı araştırmacılar tarafından yürütülen diğer çalışmalar (Petty ve Andrews, 2008; Wei vd., 2008; Huang, 2009; Campbell vd., 2013) tüketici tutumunu tespit etmeye ve stratejinin etiksel algılanmasını açıklamaya yönelik olarak gerçekleşmiştir.

Örtülü pazarlama stratejisi, tüketicinin algısının üzerinde hareket etmektedir. Bu strateji olumlu ağızdan ağıza iletişim yaratmak amacıyla insanları en savunmasız anında yakalayarak, ürünün yoğun ve kalabalık olan pazar yerinde farkına varılmasını sağlamaktadır (Kaikati ve Kaikati, 2004:6). Bunu gerçekleştirirken reklam veren ile mesaj arasında doğrudan var olan bağlantıyı açığa vurmadan, ürün tanıtımı yapılmaktadır (Scanlon ve Hearn, 2006:1). Firmanın kontrolü altında gerçekleşen iletişim sürecinde, firmanın kimliği ve/veya iletilen mesaj üzerinde kullanılan örtü sayesinde, bilinçli ve kontrollü olarak alıcıya belirli seviyede ifşa edilmektedir. Yeni dönemin stratejisi doğru zamanda, profesyonelce tasarlanarak, uygulanması halinde firmalara güvenilirlik, olumlu yayılım, satışların artması, maliyet avantajı, riskin azaltılması ve mesajın ayırt edilebilmesi gibi bir takım önemli avantajlar sunmaktadir (Ahmed, 2000; Kaikati ve Kaikati, 2004:6; Kuhn, Hume ve Love, 2010). Eğer örtülü pazarlama stratejisi yanlış kişilerce yanlış kurgulanması durumunda tüketicinin kendisinin aldatıldığını düşünmesine neden olabileceği gibi uygulama tekniğinin doğru seçilmemesi de arzu edilmeyen sonuçlar doğurabilme riski söz konusu olacaktır.

Örtülü pazarlama, tüketici ile iletişime geçilebilecek her yerde ve zamanda kendisine uygulama alanı bulabilen esnek ve çok yönlü bir stratejidir. Bu bakımdan sınırlarının nerelere kadar gidebileceği pazarlamacıların hayal güçlerine bağlıdır. Günlük yaşam içerisinde kafe, bar, alışveriş merkezi veya sosyal paylaşım sitelerinde bu stratejinin uygulama teknikleriyle karşılaşabilmek mümkündür. İletişim sürecinde gerçek kaynak ve/veya mesaj üzerinde örtü kullanarak tüketiciyle iletişime geçmekte kullanılan, birbirine benzerlik gösterse de biçimsel olarak birbirinden farklı olan ve örtülü pazarlama stratejisi kapsamında yer alan şimdilik 21 tekniğin olduğu tespit edilmiştir. Firma uygulamalarından ve alanyazını incelemesi neticesinde belirlenen bu teknikler için iletişim sürecinde kullanılan örtü seviyesine göre tipoloji önerisi geliştirilmiştir. Geliştirilen tipoloji aşağıda yer alan Tablo 1'de ayrıntılı olarak gösterilmektedir. Yapılan sınıflandırmada yer alan tekniğin baskın olarak uygulanma şekli göz önünde bulundurulmuştur. Hücre içerisinde yer alan tekniklerin birbiri arasında geçişi söz konusu olabilmektedir. Tiplojinin ilk hücresinde gerçek kaynak ve mesajın her ikisinin birden açık olduğu uygulamalar yer almaktadır ve bu hücre geleneksel pazarlama iletişim yöntemlerinden oluşmaktadır. Mesajın açık, gerçek kaynağın ise örtülü olduğu hücrede yer alan tekniklerde genelde firmanın kimliğinin maskelendiği, buna karşıllık mesajın açık olarak iletildiği görülmektedir. Bu nedenle ikinci hücreye maskeli teknikler adı verilmiştir. Dolaylı tekniklerde ise mesajın dolaylı anlatımlarla alıcıya ulaştırıldığı ve firmanın kimliğinin genellikle alıcı tarafindan rahatlıkla tespit edilebildiği teknikler yer almaktadır. Matrisin son hücresinde yer alan teknikler ise kurgulanması ve uygulanması aşamasında kurnazlıklar içermesi nedeniyle tilki teknikler olarak adlandırılmıştır. 
Tablo 1. Gerçek Kaynak ve Mesaj Üzerinde Örtü Kullanım Seviyesine Göre Tipoloji

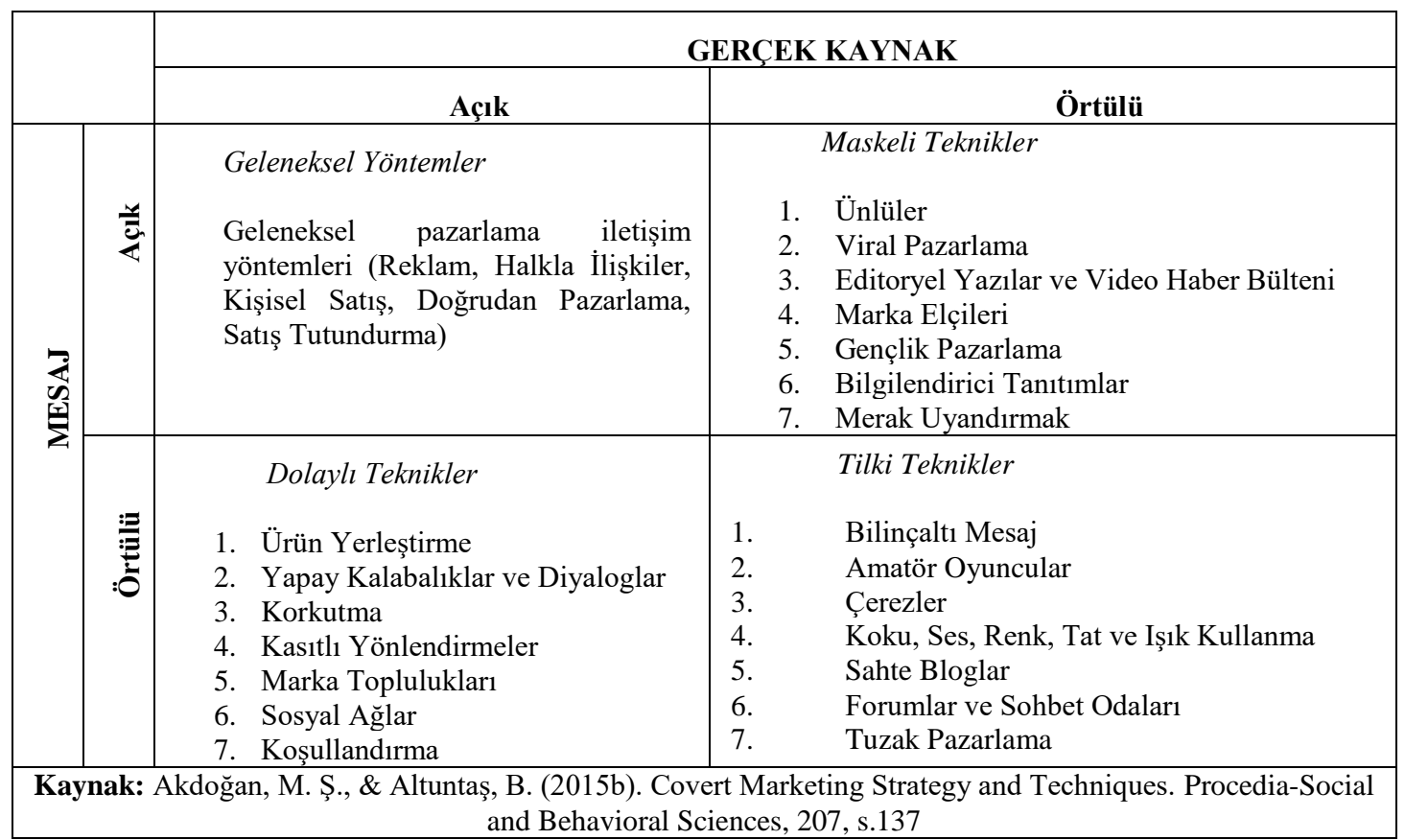

\section{Araştırma Yöntemi}

\subsection{Amacı ve Hipotezleri}

$\mathrm{Bu}$ araştırmada tüketiciyle iletişim sürecinde gerçek kaynak ve mesaj unsurları üzerinde kullanılan örtünün tüketici tutumu ve tekniğin etkinliğini değerlendirmesi üzerinde etkisinin olup olmadığı sorusuna yanıt aranmaktadır. Kullanılan örtü seviyesinin (açık/örtülü olmasının) tüketicide belirli bir etki yaratacağı ve iletişim süreci açısından bu örtü seviyesinin önemli olduğu düşünülmektedir. Ayrıca tüketicilerin demografik özelliklerine göre örtülü pazarlama uygulamalarına yönelik tutum ve değerlendirmelerinde farklılıkların olabileceği öngörülmektedir. Bu doğrultuda iki hipotez geliştirilmiştir:

H1:Kullanılan örtü seviyesinin tüketicinin tutumu ve uygulanan tekniğin etkinliğini değerlendirmesi üzerinde etkisi vardır.

H2:Demografik özellikleri bakımından tüketicilerin, kullanılan örtü seviyesine göre tutum ve tekniğin etkinliğini değerlendirmeleri arasında farklılık vardır.

\subsection{Araştırmanın Tasarımı}

Geliştirilen hipotezlerin test edilmesi için ihtiyaç duyulan veri, anket yöntemiyle toplanmıştır. Araştırmanın hedef kitlesini üniversite öğrenimi gören genç bireyler oluşturmaktadır. Zira üniversitelerin homojen yapıya sahip olması, öğrencilerin elde ettikleri gelirleri harcama eğilimleri, içinde bulundukları sosyal çevrede birbirinden etkilenme potansiyelinin yüksek olması, kolay ve düşük maliyetle kendilerine ulaşılabilmesi nedenlerinden dolayı bu kitle tercih edilmiştir. Ayrıca gençlerin üniversite yıllarında edindikleri deneyimleri ve geliştirdikleri tutumları, onların gelecekteki davranışlarını da etkilediği bilinmektedir (Altuntaş, 2009). Katılımcıların örtülü pazarlamaya yönelik 
tutumlarını tespit edebilmek ve uygulanan tekniği değerlendirmelerini belirleyebilmek amacıyla, bu kişilerin manipüle edilmesi gerekmektedir. Katılımcıları manipüle etmek için senaryo tekniği kullanılmıştır. Gerçek kaynak (açık/örtülü) ve mesaj (açık/örtülü) üzerinde kullanılan örtü seviyesine göre 4 farklı kombinasyona göre senaryolar oluşturulmuştur. Senaryoların gerçekçi olabilmesi ve katılımcıların istenilen düzeyde manipüle edebilmesi için öncelikli olarak örnek kütlenin yapısına uygun olan gençlik pazarlaması ve amatör оуипси tekniklerine göre senaryolar kurgulanmıştır. Ardından bir takım ön çalışmalar yürütülerek senaryo içerisinde kullanılacak olan ürün kategorisi (cep telefonu) ve markası (NewPhone) belirlenmiştir. Son aşamada her bir senaryoda kullanılan örtü seviyesi katılımcılar tarafından değerlendirilmiş, gerekli düzenlemeler sonrasında anket formunun tasarımına geçilmiştir.

Anket formu görüşme cetveli şeklinde hazırlanmıştır ve kapak sayfası dâhil olmak üzere dört sayfadan oluşmaktadır. Gerçek kaynak ve mesajın örtülü olduğu birinci senaryo A formuna, gerçek kaynağın örtülü mesajın açık olduğu senaryo B formuna, gerçek kaynağın açık mesajın örtülü olduğu senaryo $C$ formuna, son olarak gerçek kaynağın ve mesajın açık olduğu senaryo D formuna yerleştirilmiştir. Böylelikle her bir katılımcı yalnızca tek bir tür senaryoyu okuyarak, anket sorularına yanıt vermeleri sağlanmıştır.

Araştırmanın örtü seviyesi (açık/örtülü) ve demografik özellikleri (cinsiyet, yaş, medeni hal, ailenin aylık geliri, eğitim bölümü) olmak üzere iki bağımsız değişkeni; tutum ve tekniğin etkinliği olarak iki bağımlı değişkeni bulunmaktadır. Tüketiciler ürüne, markaya ve pazarlama iletişim tekniğine yönelik tutum geliştirmektedirler ve bu tutumları satın alma niyetini, satın alma davranışını ve bağlllıklarını etkilemektedir (Dursun ve Kabadayı, 2012:77). Bu çalışma kapsamında tutum bağımlı değişkenini belirleyebilmek için etkilenme düzeyi, örtülü tekniğe, markaya ve firmaya yönelik tutum ölçekleri kullanılmıştır. Bu ölçekler sol tarafa olumsuz, sağ tarafa olumlu ifadelerin yerleştirildiği 7 noktalı anlamsal farklılık ölçekleri olarak tasarlanmıştır. Etkilenme düzeyini belirlemek için Madden, Allen ve Twible (1988) tarafından geliştirilen etkilenme indeksi (affect index) ölçeğinden 4 ifade çifti alınmıştır. Örtülü tekniğe yönelik tutumu tespit etmek için önceki yıllarda reklama yönelik tutumu ölçmek için çeşitli araştırmacılar (MacKenzie, Lutz, Belch, 1986; Holbrook, Batra, 1987; Madden, Allen, Twible,1988; Shiv, Edell, Payne, 1997; Yağc1, Biswas, Dutta, 2009) tarafından kullanılan ölçeklerden alınan 7 ifade çifti uyarlanarak kullanılmıştır. Markaya ve firmaya yönelik tutumu ölçmek için ise kullanılan 3'er ifade çifti MacKenzie, Lutz, Belch (1986), Shiv, Edell, Payne (1997) ve Yağcı, Biswas, Dutta (2009) tarafindan kullanılan ölçeklerden alınmıştır. Araştırmanın ikinci bağımlı değişkeni uygulanan tekniğin etkinliğidir. Tekniğin etkin olup olmaması amaçlarına ne kadar ulaştığıyla ilgilidir. Bu araştırmada uygulanan tekniğin etkinliğini ölçmek için tüketicilerin satın alma niyeti, aktaran kaynak olma durumu ve etiksel algılamaları olmak üzere 3 farklı ölçek kullanılmıştır. 7 noktalı anlamsal farklılık ölçeği şeklinde anket formuna yerleştirilen bu ölçeklerden ilki Mackenzie vd. (1986), Yağcı vd. (2009) ve Zhang, Buda (1999) tarafindan çalışmalarında kullanmış oldukları satın alma niyeti ölçeğinden 3 ifade alınmıştır. Aktaran kaynak olma niyetini ölçmek için katılımcılara "senaryoyu bir bütün olarak düşündügünüzde .... marka ürününü çevrenize nasıl anlatırsınız?" şeklinde bir soru sorularak tarafımızca belirlenen 2 ifade çiftini (tavsiye ederim/etmem; olumlu/olumsuz) değerlendirmeleri istenilmiştir. Etiksel algılamayı ölçmek için ise Beltramini (1988)'nin çalışmasında yer alan 3 ifade çifti kullanılmıştır. Katılımcıya “.... ürün tanıtım faaliyetlerinde böyle bir yöntemin kullanılmasını nasıl değerlendiriyorsunuz?" sorusu yöneltilerek değerlendirmesi istenilmiştir. 
Saha çalışmasına geçmeden önce hazırlanan anket formunda yer alan ifadelerin ve soruların katılımcılar tarafından doğru biçimde anlaşılıp anlaşılmadığını belirlemek ve araştırmanın amacına uygun olup olmadığını tespit etmek için rastgele seçilen 40 öğrenciye ön test uygulanmıştır. Bu aşamada ankette yer alan ifadelerin anlaşılabilirliği, ortalama anket yanıtlama süresi ve ölçekler ile ifadelerin anket formu içerisindeki sıralamaları kontrol edilmiştir. Ardından anket tasarımı konusunda çalışmalar yapmış akademisyenlerinde görüşleri alınarak, anket formuna son hali verilmiştir.

Hazırlanan anket formlarının uygulanacağı örnek hacminin belirlenmesinde \%95 güven aralığında, hareket edilmiştir. Üniversite öğrenimi gören birey sayısının bilinmesinden dolayı 384 kişinin örnek kütle içerisinde yer almasının optimum olduğu yönünde hesaplama yapılmıştır. Hatalı doldurmaya karşı ihtiyatlı hareket edilerek her bir anket formu türünden 500 olmak üzere toplam 2.000 kişiye ulaşılması hedeflenmiştir. Ahi Evran Üniversitesi birimlerinde gerçekleştirilen saha çalışmasında, katılımcılar öğrenim gördükleri fakülte, bölüm ve sınıfına göre ayırıma tabi tutulmuş ve yargısal örnekleme yöntemine göre veri toplanmıştır. Bu yöntemde örneğe kimlerin seçileceğine deneyimli ve uzman görüşleri ile konuyu en iyi bilen araştırmacı karar verebilmektedir (İslamoğlu ve Alnıaçık, 2013:190; Nakip, 2006:204-205). Böylelikle belirli bölüm ya da sinıflarda yığılmalarının önüne geçilerek, birçok farklı birim, bölüm ve sınıflardan veri toplanabilmiştir. Saha çalışması Mayıs-Haziran 2014 ayları arasında yüzyüze görüşme yöntemiyle uygulanmıştır. Uygulama esnasında katılımcılara farklı kitapçıkların olduğu açıklanmamış ve kitapçıklar dağıtılmadan önce kendi içerisinde karıştırılarak, tesadüfi olarak dağıtılmıştır. Saha çalışması sonucunda veri analizinde kullanılabilecek niteliklere sahip 1.506 anketin olduğu görülmüştür. Kat1lımcıların \%25'i A grubu, \%27'si B grubu, \%23'ü C grubu ve \%25'i D grubu anket formlarını cevaplandırmışlardır.

\subsection{Veri Analizi}

Sahadan toplanan veriler elektronik ortama aktarıldiktan sonra SPSS 21.0 ve Lisrel 8.51 programları kullanılarak analizler gerçekleştirilmiştir. Analizlerde öncelikle katılımcılara ilişkin demografik bilgiler (Tablo 2) ve anket formunda kullanılan ölçeklerin faktör yapıları ile güvenilirlik analizleri (Tablo 3) hesaplanmıştır.

Tablo 2. Katılımcıların Demografik Özellikleri

\begin{tabular}{|l|l|l|}
\hline Cinsiyet & Frekans & Yüzde (\%) \\
\hline Kadın & 644 & 43 \\
\hline Erkek & 862 & 57 \\
\hline Toplam & 1,506 & 100 \\
\hline
\end{tabular}

\begin{tabular}{|l|l|l|}
\hline Medeni Durum & Frekans & Yüzde (\%) \\
\hline Bekar & 1,447 & 96 \\
\hline Evli & 59 & 4 \\
\hline Toplam & 1,506 & 100 \\
\hline
\end{tabular}

\begin{tabular}{|l|l|l|}
\hline Yaş Aralığı & Frekans & Yüzde (\%) \\
\hline 20 ve Aşağısı & 548 & 36,4 \\
\hline $21-24$ Arası & 867 & 57,6 \\
\hline 25 ve Yukarıs1 & 91 & 6 \\
\hline Toplam & 1,506 & 100 \\
\hline
\end{tabular}

\begin{tabular}{|l|l|l|}
\hline Eğitim Alanı & Frekans & Yüzde (\%) \\
\hline Teknik Programlar & 730 & 48 \\
\hline Sosyal Programlar & 439 & 29 \\
\hline Sağlık Programları & 337 & 22 \\
\hline Toplam & 1,506 & 100 \\
\hline
\end{tabular}




\begin{tabular}{|l|l|l|}
\hline Aile Geliri Aylık/TL) & Frekans & Yüzde (\%) \\
\hline 900 TL ve Alt1 & 161 & 11 \\
\hline $901 \mathrm{TL}-1.200 \mathrm{TL}$ & 261 & 17 \\
\hline $1.201 \mathrm{TL}-3.850 \mathrm{TL}$ & 991 & 66 \\
\hline $3.851 \mathrm{TL}$ ve Üstü & 93 & 6 \\
\hline Toplam & 1,506 & 100 \\
\hline
\end{tabular}

\begin{tabular}{|l|l|l|}
\hline & Yaş & Gelir \\
\hline Geçerli & 1,506 & 1,506 \\
\hline Ortalama & 22 & $1.946 \mathrm{TL}$ \\
\hline Medyan & 21 & $1.950 \mathrm{TL}$ \\
\hline Minimum & 18 & $300 \mathrm{TL}$ \\
\hline Maximum & 61 & $17.000 \mathrm{TL}$ \\
\hline
\end{tabular}

Ankete katılanların \%57'si erkek, \%43'ü ise kadındır. En küçüğü 18 en büyüğü 61 yaşında olan katılımcıların yaş dağılımı ağırlıklı olarak 21 ila 24 yaş arasındadır. Anketin örnek kütlesi üniversite öğrenimi gören öğrenciler olduğundan, eğitim değişkeni "okuduğunuz bölüm nedir?" olarak sorulmuştur. Elde edilen yanıtlara göre katılımcılar teknik, sosyal ve sağlık bilimler olmak üzere üç program altında toplanmıştır. Gruplandırmaya göre katılımcıların \%48'i teknik ağılıklı programlarda öğrenim görürken, \%29'u sosyal ve $\% 22$ 'si de sağlık bilimleri programlarında öğrenim görmektedir. Gelir değişkeni verinin toplandığı dönemde geçerli olan asgari ücret, açlık ve yoksulluk sınırları temel alınarak ayrıma tabi tutulmuştur. Buna göre katılımcıların ailelerinin aylık ortalama geliri 1.946 TL'dir ve \%66’lık büyük bir bölümü açlık sınırı gelir grubu içerisinde yer almaktadır.

Katılımcıların demografik bilgilerinin değerlendirilmesinin ardından kullanılan tutum ve tekniğin etkinliği ölçeklerinin güvenilirlik katsayıları ile faktör yapıları hesap edilmiştir. Tablo 3.'te sunulan sonuçlar ölçeklerin yeterli düzeyde güvenilir olduğunu ve her bir ölçekte baskın olan tek faktörün toplam varyansın büyük kısmını açıkladığı görülmüştür.

Tablo 3. Kullanılan Ölçeklerin Güvenilirlik Katsayısı ve Faktör Yapıları

\begin{tabular}{|l|c|c|c|}
\hline \multicolumn{1}{|c|}{ Kullanılan Ölçek } & $\begin{array}{c}\text { Cronbach's } \\
\text { Alpha }\end{array}$ & Özdĕgeri & $\begin{array}{c}\text { Toplam } \\
\text { Varyans }\end{array}$ \\
\hline Etkilenme İndeksi (Eİ) & 0,885 & 2,977 & 74,419 \\
\hline Yönteme Yönelik Tutum (YYT) & 0,896 & 4,545 & 64,935 \\
\hline Markaya Yönelik Tutum (MYT) & 0,891 & 2,467 & 82,228 \\
\hline Firmaya Yönelik Tutum (FYT) & 0,910 & 2,546 & 84,456 \\
\hline Satın Alma Niyeti (SAN) & 0,788 & 1,652 & 82,625 \\
\hline Aktaran Kaynak Olma (AKO) & 0,878 & 1,783 & 89,173 \\
\hline Etiksel Algılama (EA) & 0,704 & 1,892 & 63,074 \\
\hline
\end{tabular}

\subsection{Kullanılan Örtünün Etkisinin Analiz Edilmesi}

Senaryolarda kullanılan örtü seviyesinin tutum ve tekniğin etkinliği üzerinde etkisinin olup olmadığını tespit edebilmek için öncelikle katılımcıların vermiş oldukları yanıt ortalamaları hesaplanmıştır. Elde edilen sonuçlar Tablo 4.'te gösterilmektedir. 
Tablo 4. Kullanılan Örtü Seviyesi ile Ölçeklerin Ortalaması

\begin{tabular}{|l|c|c|c|c|c|c|c|c|}
\hline \multicolumn{1}{|c|}{ ÖS } & $\mathbf{n}$ & $\mathbf{E \dot { I }}$ & YYT & MYT & FYT & SAN & AKO & EA \\
\hline GK/Ö-M/Ö & A (375) & 3,99 & 4,03 & 4,06 & 4,26 & 3,57 & 4,09 & 3,71 \\
\hline GK/Ö-M/A & B (410) & 3,77 & 3,93 & 4,10 & 4,20 & 3,68 & 4,27 & 3,54 \\
\hline GK/A-M/Ö & C (340) & 5,47 & 4,79 & 4,82 & 5,25 & 4,25 & 5,00 & 3,76 \\
\hline GK/A-M/A & D (381) & 5,46 & 4,83 & 4,89 & 5,43 & 4,40 & 5,10 & 3,51 \\
\hline Toplam & $\mathbf{1 5 0 6}$ & $\mathbf{4 , 6 4}$ & $\mathbf{4 , 3 8}$ & $\mathbf{4 , 4 3}$ & $\mathbf{4 , 7 6}$ & $\mathbf{3 , 9 6}$ & $\mathbf{4 , 6 0}$ & $\mathbf{3 , 6 3}$ \\
\hline
\end{tabular}

ÖS: Örtü Seviyesi; n: Katılımcı Sayıs1; Eİ: Etkilenme İndeksi; YYT:Yönteme Yönelik Tutum; MYT:Markaya Yönelik Tutum; FYT:Firmaya Yönelik Tutum; SAN:Satınalma Niyeti; AKO:Aktaran Kaynak Olma; EA:Etiksel Algılama; GK: Gerçek Kaynak; M: Mesaj; Ö: Örtülü; A: Açık

Gerçek kaynak üzerinde kullanılan örtü seviyesinin etiksel algılama ölçeği dışında diğer bütün ölçekler üzerinde etkisinin olduğu görülmektedir. Gerçek kaynağın üzerinin açık olması durumunda, gerçek kaynağın üzerinin örtülü olmasına kıyasla yanıt ortalamaları daha yüksektir. Mesajın üzerinde kullanılan örtünün, yanıt ortalamalarında pek fazla bir farklılık yaratmadığ yine tabloda görülmektedir.

Katılımcıların verdiği cevap ortalamaları arasında var olan bu farklılıkların istatistiki olarak anlamlı olup olmadığını tespit edebilmek için veriye çok değişkenli varyans analizi uygulanmıştır. Bilindiği üzere manova analizi gruplar boyunca, değişken korelasyonlarının eşit olduğu varsayımını kabul etmektedir. Çoklu varyans analizindeki bağımlı değişkenlerin kovaryans matrislerinin homojenliği Box's M ile test edilmiş (Box's $M=450,387 ; p=0,001$ ) ancak doğrulanamamıştır. Böyle durumlarda eğer grup büyüklük miktarları farklılaşıp, Box’s M testi anlamlılık sonucu kabul edilemeyecek seviyede ise araştırmacının elinde bir takım seçeneklerin olduğu bildirilmektedir (Hair vd., 2009: 361-362). Dağılımı normal dağılıma benzetmek ve grup karşılaştırmalarındaki varyans homojenliğini sağlayabilmek için geliştirilmiş dağılım dönüştürme yöntemleri bulunmaktadır. Veri setindeki her bir gözleme uygun matematiksel bir yöntem seçilerek yapılan dönüştürme işlemi sonrasında, istatistiksel analiz bu dönüştürülmüş gözlemlerle yapılmaktadır (Ovla ve Taşdelen, 2012:5). Bu seçeneklerden birisi, varyans dengeleme dönüşümünün yapılmasıdır. Bunun için logaritmik dönüşüm $(\mathrm{z}=\log \mathrm{y})$ uygulanmış ve test tekrar edilmiştir. Box's $\mathrm{M}$ testi anlamlılık sonucunda herhangi bir değişim meydana gelmemiştir. Ancak bu sonuç araştırmanın hedeflerinden sapmalara neden olacak bir durum değildir; örtü seviyesinin bağımsız olarak etkilerinin olabileceğine işaret etmektedir. Örtü seviyesine göre tutum ve tekniğin etkinliği değişkenlerinin aynı anda analize katılması ile gruplar arasında farklılık olup olmadığını gösteren manova tablosu incelenmiş ve örtü seviyesinin, tutum ve tekniğin etkinliğinde en az bir grup arasında anlamlı farklılı olduğunu göstermiştir (Wilk's $\lambda=0,765 ; \mathrm{F}=20,023 ; \mathrm{p}<0,0001)$.

Örtü seviyesinin bağımlı değişkenler üzerinde etkisinin olduğunu görebilmek amaciyla tek değişkenli analiz sonuçlarına bakılmıştır. Düzeltilmiş modele göre, bağımlı değişkenler açısından grup ortalamalarının, etiksel algılama dışında eşit olmadığı hesap edilmiştir. Aşağıda yer alan Tablo 5. analiz sonuçları gösterilmektedir. 
Tablo 5. Tek Değişkenli Analiz Sonuçları

\begin{tabular}{|c|c|c|c|c|c|c|c|}
\hline Kaynak & Bağımlı Değişken & $\begin{array}{c}\text { Tip 3 } \\
\text { K.Topl }\end{array}$ & SD & Ort.Kr. & $\mathbf{F}$ & $\mathbf{p}$ & $\begin{array}{l}\text { P. Eta } \\
\text { Karesi }\end{array}$ \\
\hline \multirow{7}{*}{ Örtü Seviyesi } & Etkilenme Düzeyi & 955,600 & 3 & 318,533 & 126,116 &, 000 & ,201 \\
\hline & Yönteme Yönelik T. & 262,560 & 3 & 87,520 & 35,287 &, 000 & ,066 \\
\hline & Markaya Yönelik T. & 206,692 & 3 & 68,897 & 20,315 & ,000 & ,039 \\
\hline & Firmaya Yönelik T. & 473,702 & 3 & 157,901 & 50,793 &, 000 & ,092 \\
\hline & Satın Alma Niyeti & 191,254 & 3 & 63,751 & 17,394 &, 000 &, 034 \\
\hline & Aktaran Kaynak O. & 289,758 & 3 & 96,586 & 26,488 &, 000 &, 050 \\
\hline & Etiksel Algılama & 16,982 & 3 & 5,661 & 2,116 & ,096 & ,004 \\
\hline
\end{tabular}

Test sonuçlarına göre gerçek kaynak üzerinde örtü kullanılmasının tutum ve tekniğin etkinliği cevapları üzerinde, etiksel algılamaları dışında istatistiki olarak anlamlı etkisinin olduğu görülmüştür. Bu bulgu doğrultusunda oluşturulan H1: Kullanilan örtü seviyesinin tüketicinin tutumu ve uygulanan tekniğin etkinliğini değerlendirmesi üzerinde etkisi vardır hipotezi de sınanmış ve kullanılan örtü seviyesinin etkisi olduğu görülerek, etiksel algılama dışında diğer değişkenler açısından kısmen kabul edilmiştir.

\subsection{Demografik Faktörlerin Etkisinin Analizi}

Tüketicilerin sahip oldukları demografik özelliklerin tutum oluşmasında ve tekniğin etkinliğini değerlendirmesi üzerinde etkisinin olduğu varsayımını doğrulamak için öncelikle teorik evrende yapısal model kurgulanmıştır. Yapısal model kurgulanırken örtük değişkenlerin en az iki ya da üç gözlenen değişken ile tanımlanması gerektiği bildirilmektedir (Kline, 2011). Ancak demografik değişkenler tek gözlenen değişkenli örtük değişken olduğundan model yol analizi ile sınanabilecektir. Kurgulanan yapısal model aşağıda yer alan Şekil 1.'de verilmiştir bu modele göre demografik özellikler tutum oluşumu ve tekniğin etkinliğini değerlendirme üzerinde etkisi bulunmaktadır. Yapısal eşitlik model analizi ile bu etkinin varlığı ya da yokluğu test edilecektir.

Şekil 1. Demografik Faktörler Yapısal Modeli

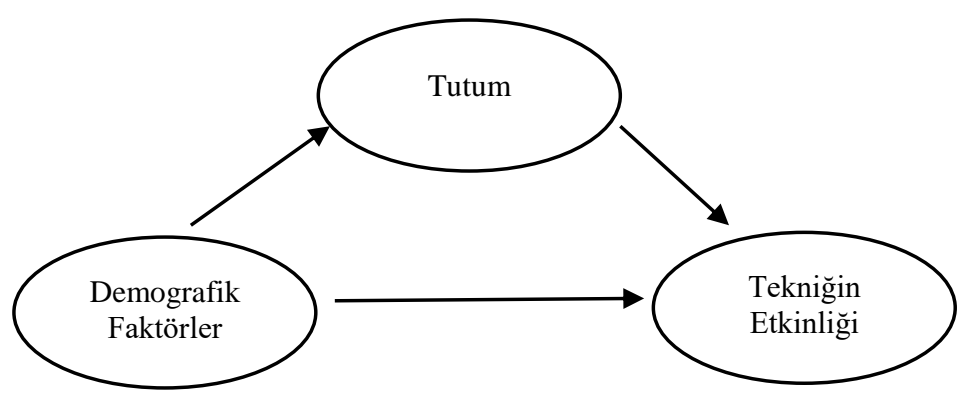

Yapısal modelin testine geçmeden önce ölçüm modelinin t-değerleri hesaplanmıştır. Sonuçların olumlu olması ve uyum iyiliği istatistiklerinin de yeterli seviyede olması ile yapısal model testine geçilmiştir (GFI:0.95; AGFI:0.94; CFI:0.80; RMSEA:0.04; $X^{2} / d f$ : 
1.63). Demografik faktörlerle kurulan model ve yol analizi sonuçları aşağıda yer alan Şekil 2 'de gösterilmektedir.

Şekil 2. Demografik Faktörler Yol Analizi (Standart Değerler)

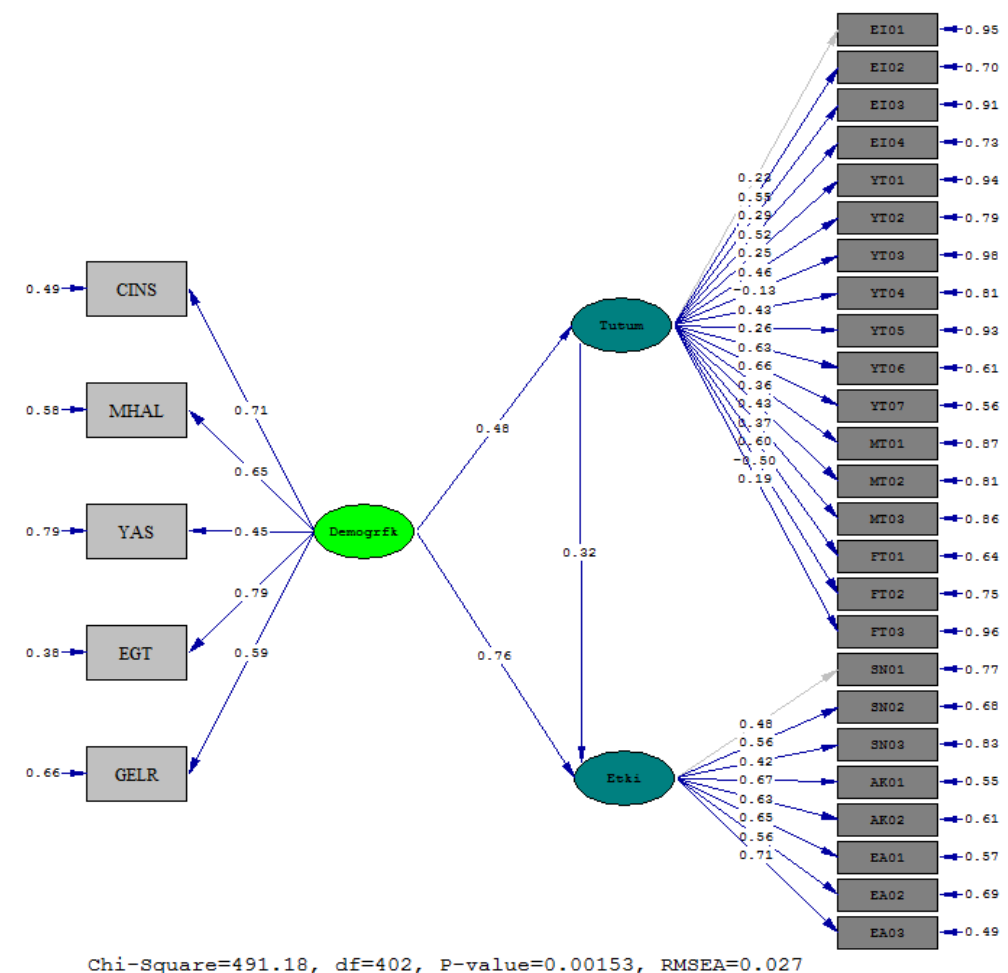

Demografik değişkenlerden tutuma giden yolun parametre değeri 0.48 'dir ve bu değişkenlerin tutum üzerinde orta düzeyde etkisinin olduğu söylenebilir. Tutum ile tekniğin etkinliği arasındaki ilişki düzeyi de orta derecededir (0.32). Demografik değişkenlerin tekniğin etkinliği üzerindeki etkisi 0.76 gibi oldukça yüksek hesap edilmektedir. Ayrıca kontrol edilen uyum iyiliği istatistikleri modelin veriyle son derece uyumlu olduğunu göstermiștir ( $X^{2} / d f$ : 1.22; GFI:0.95; AGFI:0.94; CFI:0.90; RMSEA:0.027; IFI:0.90; NNFI:0.89). Analiz neticesinde demografik değişkenlerin tutum ve tekniğin etkinliği değişkenlerinin her ikisinde birden orta ve yüksek seviyede etkisinin olduğu belirlenmiş ve kurgulanan yapısal model doğrulanmıştır.

\subsubsection{Demografik Özelliklerine Göre Gruplar Arasında Farklılık Testi}

Katılımcıların demografik özelliklerine göre (cinsiyet, medeni durum, yaş, eğitim alanı ve aile geliri) gruplar arasında tutumları ve tekniğin etkinliğini değerlendirmeleri arasında farklılık olup olmadığını tespit edebilmek amacıyla veriye t-testi ile varyans analizi uygulanmıştır. Buna göre;

Ankete katılan kadın (644 )ve erkek (862) için etkilenme düzeyi, yönteme, markaya ve firmaya yönelik tutumları arasında anlamlı fark olup olmadığını görmek için bağımsız 
örneklem t-testi uygulanmıştır. Katılımcıların yönteme yönelik tutum $(\mathrm{F}(1504)$ : 3,814; $\mathrm{p}=0,021)$ ve etiksel algılama ortalamalarında $(\mathrm{F}(2,289) ; \mathrm{p}<0,05)$ cinsiyet değişkenine göre istatistiki olarak anlamlı bir farklılık olduğu ve kadınların, yönteme yönelik tutum ile etiksel algılama ortalamalarının, erkeklere göre daha düşük olduğu tespit edilmiştir.

Ankete katılanların 1447'si bekar, 59'u ise evlidir. Medeni durum ile tutum ve tekniğin etkinliği arasındaki ilişkiyi analiz etmek için bağımsız örneklem $t$-testi uygulanmış ve gruplar arasında istatistiki olarak anlamlı bir farklılık bulunamamıştır.

Ankete katılan 548 kişi "20 yaş ve altı" grubunda iken 867 kişi "21 ile 24 yaş arası" ve 91 kişi de 25 yaş ve üzeri grupta yer almaktadır. Yaş gruplarına göre tutumları ve tekniğin etkinliği arasında anlamlı farkların olup olmadığını tespit etmek için tek yönlü varyans analizi (Anova) uygulanmıştır. Yapılan analize göre yanıt ortalamaları arasında farklılıklar tespit edilmesine rağmen bu farklılıkların istatistiki olarak anlamlı olmadığı görülmüştür.

Ankete katılanlardan 730 kişi teknik, 439 kişi sosyal ve 337 kişi de sağlık ağırlıklı bir programda eğitim görmektedir. Kişilerin eğitim alanları ile tutum ve tekniğin etkinliği ölçeklerine vermiş oldukları cevap ortalamalarına tek yönlü varyans analizi (Anova) uygulanmıştır. Anketi cevaplayanların eğitim alanı ile etkilenme düzeyi ( $\mathrm{F}(2,1503): 22,32$; $\mathrm{p}<0,05)$; yönteme yönelik tutum $(\mathrm{F}(2,1503): 19,32 ; \mathrm{p}<0,05)$; markaya yönelik tutum $(\mathrm{F}(2,1503): 17,44 ; \mathrm{p}<0,05)$ ve firmaya yönelik tutum $(\mathrm{F}(2,1503): 25,22 ; \mathrm{p}<0,05)$; satın alma niyeti $(\mathrm{F}(5,36 ; \mathrm{p}<0,001)$, aktaran kaynak olma $(\mathrm{F}(17,11 ; \mathrm{p}<0,001)$ ve etiksel algilama $(\mathrm{F}(11,24 ; \mathrm{p}<0,001)$ ortalamaları arasında anlamlı düzeyde farklılıklar olduğu görülmüsştür.

Aile gelirinin kişilerin, etkilenme düzeylerinde ve tutuma ilişkin cevap ortalamalarında farklı1ık oluşturup oluşturmadığını tespit etmek için tek yönlü varyans analizi (Anova) uygulanmıştır. Sonuçlara göre, kişilerin aile gelirleri ile tutumları ve tekniğin etkinliğini değerlendirmeleri arasında anlamlı farklılıkların olmadığını tespit edilmiştir.

Genel olarak demografik değişkenler ile tutum ve tekniğin etkinliği ölçekleri ortalamaları arasındaki farklılıklar incelendiğinde eğitim alanı değişkeninin tutum ve tekniğin etkinliği değişkenlerine etki eden önemli bir değişken olduğu görülmüştür. Ayrıca cinsiyet değişkenin de yönteme yönelik tutum ve etiksel algılama ortalamalarında anlamlı farklılık olduğu tespit edilmiştir. Eğitim alanı ile cinsiyet değişkenlerinin etkileri ileri analizler ile incelenmeye devam edecektir.

\subsubsection{Cinsiyet ve Eğitim Alanı Değiş̧kenlerinin Detaylı İncelenmesi}

$\mathrm{Bu}$ bölümde cinsiyet ve eğitim alanı değişkenleri senaryolarda kullanılan örtü seviyesi ile birlikte dikkate alınarak gruplar arasında farklılık olup olmadığı ayrıntılı olarak incelenmiştir. Bu ilişki çok değişkenli varyans analizi (manova) kullanılarak test edilmiştir.

Cinsiyet ve örtü seviyesinin birlikte değerlendirildiği çok değişkenli test sonuçlarına göre gruplar arasında anlamlı farklılıklar olduğunu göstermiştir. Bu farklılığın hangi bağımlı değişkenlerde ve hangi düzeyde ortaya çıktığını görebilmek için tek değişkenli test sonuçlarına bakmakta fayda görülmektedir. Bu bakımdan aşağıda yer alan Tablo 6'da manova testi tek değiş̧kenli analiz tablosu verilmiştir. Tabloda bağımsız değişkenin her bir bağımlı değişken üzerindeki etkisi gösterilmektedir. 
Tablo 6. Cinsiyet ve Örtü Seviyesi Manova Testi Tek Değişkenli Analizi

\begin{tabular}{|c|l|l|l|l|l|l|l|}
\hline \multirow{2}{*}{ Kaynak } & \multicolumn{1}{|c|}{ Bağımlı Değişken } & $\begin{array}{c}\text { Tip 3 } \\
\text { K.Topl. }\end{array}$ & SD & Ort.Kare & F & p & $\begin{array}{c}\text { Partial } \\
\text { Eta } \\
\text { Karesi }\end{array}$ \\
\hline \multirow{5}{*}{\begin{tabular}{l} 
Cinsiyet * \\
\multirow{4}{*}{$\begin{array}{l}\text { Örtü } \\
\text { Seviyesi }\end{array}$}
\end{tabular}} & Etkilenme Düzeyi & 49,863 & 3 & 16,621 & 6,684 &, 000 &, 013 \\
\cline { 2 - 8 } & Yönteme Yönelik T. & 23,077 & 3 & 7,692 & 3,130 &, 025 &, 006 \\
\cline { 2 - 9 } & Markaya Yönelik T. & 58,794 & 3 & 19,598 & 5,850 &, 001 &, 012 \\
\cline { 2 - 9 } & Satın Alma Niyeti & 52,611 & 3 & 17,537 & 4,830 &, 002 &, 010 \\
\cline { 2 - 9 } & Aktaran Kaynak O. & 68,461 & 3 & 22,820 & 6,325 &, 000 &, 013 \\
\cline { 2 - 9 } & Etiksel Algılama & 19,298 & 3 & 6,433 & 2,416 &, 065 &, 005 \\
\hline
\end{tabular}

Cinsiyet değişkeninin, örtü seviyesi ile birlikte değerlendirilmesi neticesinde etiksel algılama $(\mathrm{p}=0,065)$ haricinde diğer değişkenlerde gruplar arasında anlamlı farklılıkların olduğu görülmektedir. Kadın ve erkek katılımcıların, örtü seviyesine göre verdikleri cevap ortalamaları, tanımlayıcı istatistiklerden incelendiğinde, erkek ve kadın katılımcıların gerçek kaynağın açık olması halinde cevap ortalamalarının birbirine yakın olduğu ancak gerçek kaynağın örtülü olması durumunda kadınların erkeklere göre daha olumsuz tutum ve değerlendirmede bulundukları tespit edilmiştir.

Eğitim alanı ile örtü seviyesi de ayrıntılı olarak analiz edebilmek için çok değişkenli varyans analizi uygulanmıştır. Çok değişkenli test tablosuna göre eğitim ve örtü seviyesinin ayrı ayrı yanıt ortalamaları üzerinde anlamlı farklılık olduğunu ancak her iki değişkenin birlikte analize katılması halinde anlamlı farklılığın olmadığı görülmüştür. Bu durumu daha ayrıntılı tespit edebilmek ve bağımlı değişkenlerin her birinde farklı neticeler olabileceği ihtimali göz önünde bulundurularak, tek değişkenli analiz uygulanmıştır. Tablo 7.'de manova tek değişkenli analizi raporu verilmiştir. Eğitim alanı ve örtü seviyesinin etkileşim faktörü kontrol edildiğinde firmaya yönelik tutum, satın alma niyeti ve aktaran kaynak olma üzerinde anlamlı farklı1ığın olduğu tespit edilmiştir. Diğer değişkenlerde herhangi bir anlamlı farkl1lık görülmemiştir.

Tablo 7. Eğitim Alanı ve Örtü Seviyesi Manova Testi Tek Değişkenli Analiz

\begin{tabular}{|c|c|c|c|c|c|c|c|}
\hline Kaynak & Bağımlı Değişken & $\begin{array}{c}\text { Tip } 3 \\
\text { K.Topl. } \\
\end{array}$ & SD & Ort.Kare & $\mathbf{F}$ & $\mathbf{p}$ & $\begin{array}{c}\text { Partial } \\
\text { Eta Karesi }\end{array}$ \\
\hline \multirow{7}{*}{$\begin{array}{l}\text { Eğitim Alan1 } \\
\text { * Örtü } \\
\text { Seviyesi }\end{array}$} & Etkilenme Düzeyi & 27,312 & 6 & 4,552 & 1,838 &, 088 &, 007 \\
\hline & Yönteme Yönelik T. & 25,876 & 6 & 4,313 & 1,773 &, 101 & ,007 \\
\hline & Markaya Yönelik T. & 33,257 & 6 & 5,543 & 1,667 &, 125 &, 007 \\
\hline & Firmaya Yönelik T. & 44,764 & 6 & 7,461 & 2,466 & ,022 &, 010 \\
\hline & Satın Alma N. & 50,213 & 6 & 8,369 & 2,301 &, 032 & ,009 \\
\hline & Aktaran Kaynak O. & 46,589 & 6 & 7,765 & 2,170 &, 043 & ,009 \\
\hline & Etiksel Algılama & 13,843 & 6 & 2,307 &, 875 &, 513 &, 004 \\
\hline
\end{tabular}


Bağımsız değişkenlerde ortaya çıkan anlamlı farklılık sonrasında tanımlayıcı istatistiklerde hesap edilen ortalama değerler incelenmiş, bu farklılığın gerçek kaynak üzerinde kullanılan örtü seviyesinden kaynaklandığı tespit edilmiştir. Sağlık alanında eğitim gören kişiler gerçek kaynak ve mesaj üzerinde örtünün kullanılması halinde firmaya yönelik tutumu daha olumsuz olmakta, satın alma niyetleri olmamakta ve aktaran kaynak olmaya karşı olumsuz tutum içerisinde olmaktadırlar.

Cinsiyet ve eğitim alanı değişkenlerinin ayrıntılı analizi neticesinde oluşturulan $H 2$ : "Demografik özellikleri bakımından tüketicilerin, kullanılan örtü seviyesine göre tutum ve tekniğin etkinliğini değerlendirmeleri arasında farklılık vardır" hipotezi tam olarak doğrulanamamıştır.

\section{Sonuç ve Öneriler}

Günümüz işletmelerinin karşı karşıya kaldıkları önemli sorunlardan birisi tüketicilerle etkin iletişim kuramama problemidir. Tüketicisine ulaşamayan işletmeler, ürünleri hakkında onları ikna etmek bir yana ürünün ne olduğu hakkında bile bilgi aktaramayacak duruma gelmişlerdir. İşletmeler, bu sorunun üstesinden gelebilmek için sürekli olarak alternatif stratejiler, taktikler ve yöntemler geliştirmektedirler. Güncel olan bu soruna yönelik çözüm olabileceği düşünülen örtülü pazarlama stratejisi, pazarlama disiplini için yeni ufuklar açabilecek gücünün olduğunu göstermektedir. Bu bakımdan yerli alanyazınına hem teorik hem de uygulama açısından önemli katkı sağlayacak olan bu çalışma bir takım önemli sonuçlar içermektedir.

Elde edilen sonuçlara göre gerçek kaynak üzerinde örtünün kullanılıp kullanılmamasının etkilenme düzeyinde, yönteme, markaya ve firmaya yönelik tutum ve satın alma niyeti ile aktaran kaynak olma durumu üzerinde anlamlı etkisinin olduğu sonucuna ulaşılmıştır. Mesaj üzerinde kullanılan örtü seviyesinin katılımcıların tutum ve uygulanan tekniğin etkinliğini değerlendirmelerinde anlamlı farklılık yaratmadığ 1 tespit edilmiştir. Kişiler mesaja maruz kaldıklarında karşılarında firmayı açık bir şekilde görebiliyorlarsa ya da onu algılayabiliyorlarsa daha olumlu tutum içerisinde olmaktadırlar. Ayrıca da ürünü satın alma niyetleri yükselmekte ve aktaran kaynak olma potansiyelleri artmaktadır. Ancak etiksel algılama değişkeni kullanılmakta olan örtü seviyesine ve diğer değişkenlerden etkilenmediği, her durumda etiksel algılama ortalamasının orta düzeyde olduğu tespit edildiğinden, kişilerin etiksel algılamasının başkaca değişkenlerin etkisinde olduğu sonucuna ulaşılmıştır. Literatür incelemesinde örtülü pazarlama stratejisine yönelik en büyük kaygı ve yapılan eleştirilerin yoğunluğu etiksel boyutuyla ilgilidir. Örtülü pazarlama stratejilerinin etiksel kaygılar içerdiği, sivil toplum örgütleri ve birliklerinin, bu stratejinin tüketiciyi aldatıcı özelliklerinin olduğunu literatürde belirtmektedirler. Ancak Branscum (2004) ve Rotfeld (2008) yürüttükleri çalışmalarında etiksel ve aldatıcılığın olduğu yönünde ki kaygıların gereksiz olduğunu tespit etmişlerdir. Bu çalışmada da elde edilen sonuçlara göre kişilerin etiksel algılamalarında kullanılan örtünün etkisinin olmadığı tespit edilmiştir. Bir diğer ifade ile araştırmaya katılanların firma, ürün, marka, uygulanan tekniği değerlendirmelerinde ve satın alma niyeti ve aktaran kaynak olma durumu üzerinde "örtü" seviyesinin etkisinin olmadığ 1 görülmüştür. Bu bulgu Branscum ve Rotfeld'in bulguları ile benzeşmektedir. Dolayısıyla stratejinin uygulanabilirliği ve mesajın tüketiciye iletilmesi açısından önemli bir sonuç olarak değerlendirilmelidir. Ancak bu sonuç örtülü pazarlama uygulamalarının etiksel sorunu olup olmadığını net biçimde ortaya koymamaktadır. Zira örneklem ile ilgili kısıt söz konusudur. 
Gerçek kaynağın üzerinin örtülü olduğu durumlarda mesajın örtülü ya da açık olması halinde tüketicilerin tutumları ile tepkileri arasında anlamlı farklılığın olmaması, bu strateji sayesinde mesajın alıcıya ulaştırılabileceğini sonucunu doğurmaktadır. Çünkü tüketici mesajın arkasında firmanın varlığını farketmediğinden mesaj kendisine rahatlıkla ulaştırılabilmektedir. Bu durum karşısında tüketicilerin mesajın örtülü ya da açık olmasına yönelik etiksel algılamaları arasında farklılık bulunmadı̆̆ 1 da göz önünde bulundurulacak olursa, firmaların tüketiciye ulaşmasına imkan sağlayan önemli bir stratejidir. Ancak gerçek kaynak yani firmanın kendi üzerinde örtü kullanıp kullanmaması kritik bir karardır. Görünen o dur ki, tüketici mesajı algılamadığında ancak firmanın varlığını fark etmesi halinde olumsuz tepki ortaya çıkmaktadır. Tüketicinin bu tepkisinin altında kendisinin aldatılma ihtimalinin olduğu düşünülmektedir.

Yürütülen bu çalışmanın bir takım kısıtlılıkları söz konusudur. Öncelikli olarak katılımcıları maniple etmek amacıyla kullanılan senaryolarda örtülü pazarlama tekniklerinden amatör oyuncular ve gençlik pazarlaması kullanılmıştır. Bu bakımdan çalışmada elde edilen bulgu ve sonuçlar, örtülü pazarlama stratejisinin diğer uygulamalarında farklı sonuçlar verebileceği göz önünde bulundurulmalıdır. İkinci önemli sınırlılık ise seçilen ürünün cep telefonu olmasıdır. Farklı ürün gruplarında örtülü tekniklerin kullanılması, tüketiciler açısından farklı değerlendirilebilir. Bununla birlike cep telefonu ürünü için gerçekte olmayan bir marka adı kullanılması da başka bir kısıt olarak görülmektedir. Bilinen bir ürün kategorisinde bilinmeyen bir markanın yaratacağı olumsuz etki bu çalışmada göz ardı edilmiştir. Ayrıca örnek kütlenin üniversite öğrencilerinden seçilmiş olması, sonuçların genellenebilirliğini kısıtlamaktadır. Bir diğer durum ise öğrenciler sınıf ortamında, suni olarak yönlendirilmişlerdir. Dolayısıyla verilen cevaplar, normal koşullarda oluşabileceklerden farklı olabilme ihtimali söz konusudur. Araştırmanın sınırlılıkları göz önünde bulundurulduğunda, ileride yapılacak çalışmalarda farklı ürün grupları ya da ilgilenim düzeyinde ürünler ile çalışmanın yapılması; farklı üniversite öğrencileri ya da farklı tüketici grupları ile çalışılması önerilmektedir. Yürütülen bu çalışmada gerçek kaynak ile mesaj üzerinde birlikte örtünün kullanılıp kullanılmamasına göre senaryolar kurgulanarak, tüketicilerin tutumları ve uygulamanın etkinliği tespit edilmiştir. Gelecek çalışmalarda bu unsurlar ayrı ayrı ele alınıp, değerlendirilebilir. Böylelikle tüketicilerin en fazla etkilendiği ya da tepki verdiği unsurun hangisi olduğu daha net olarak ortaya konulabilir. Bu alanda yapılacak olan çalışmalarda, pazarlamanın kutsalları olarak addedilen diğer karma elemanlarında örtülü pazarlama stratejisinin uygulanması incelenebilir. Örtülü pazarlama kavram olarak ilk bakışta etiksel kaygıları kendisiyle birlikte getirmektedir. Bu nedenle gelecek çalışmaların etik konusunu daha ayrıntılı biçimde ele almaları, konuyu deontolojik ve teleolojik yaklaşımlar çerçevesinde ele almaları tavsiye edilebilir. Son <olarak mevcut rekabet koşullarında, stratejinin gelecekte pazarlamacıların gözdesi olmaya devam edeceği ve uygulama tekniklerinin farklılaşarak daha fazla yaygınlaşacağı öngörülmektedir. 


\section{KAYNAKÇA}

AHMED, S. (2000). Stealth may be the only future marketing has. Marketing, 32.

AKDOĞAN, M.Ş. ve ALTUNTAŞ, B. (2015a). Örtülü pazarlama stratejisi ve örtülü pazarlama iletişim modeli önerisi. 20. Ulusal Pazarlama Kongresi Bildiriler Kitabı, ss.279282, 10-13 Haziran, Eskişehir.

AKDOĞAN, M.Ş. \& ALTUNTAŞ, B. (2015b). Covert Marketing Strategy and Techniques. Procedia-Social and Behavioral Sciences, 207, 135-148.

ALTUNTAŞ, B. (2009). Kozmetik Sektöründe Erkek Tüketicilerin Tüketim Allşkanlıkları: Tıraş ve Tıraş Sonrası Bakım Ürünlerinde Bir Uygulama. (Yayınlanmamış Yüksek Lisans Uzmanlık Projesi). Bahçeşehir Üniversitesi, İstanbul.

AZİZAĞAOĞLU, A. ve ALTUNIŞIK, R. (2012). Postmodernizm, Sembolik Tüketim Ve Marka. Tüketici ve Tüketim Araştırmaları Dergisi, 4 (2), 33-50.

BABACAN, M. \& ONAT, F. (2002). Postmodern Pazarlama Perspektifi. Ege Academic Review,2(1),11-20

BELTRAMINI, R. F. (1988). Perceived Believability Of Warning Label İnformation Presented İn Cigarette Advertising. Journal Of Advertising, 26-32.

BORÇA, G. (2007). Bu Topraklardan Dünya Markası Çıkar Mı?.(9. Bs.). İstanbul: Mediacat Kitapları

BRANSCUM, Deborah (2004, 22 Aralı). US: Marketing Under The Radar. Corpwatch sitesinden alınmıştır. http://www.corpwatch.org/article.php?id=11762, Erişim Tarihi: 10 A ğustos 2016

BROWN, S. (1993). Postmodern Marketing? Europeanjournal Of Marketing, 27(4), 19-34.

BURTON, D. (2002). Postmodernism, Social Relations And Remote Shopping. European Journal Of Marketing, 36(7/8), 792-810.

CAMPBELL, M. C., MOHR, G. S. \&VERLEGH, P. W. (2013). Can Disclosures Lead Consumers To Resist Covert Persuasion? The İmportant Roles Of Disclosure Timing And Type Of Response. Journal Of Consumer Psychology, 23(4), 483-495.

CANŞEN, F. (2011, 21 Aralık). Örtülü Reklam Mı? O Da Ne?", http://t24.com.tr/haber/ortulu-reklam-mi o-da-ne/187959, Erişim Tarihi: 10 Ağustos 2016.

CARLSON, D. (2004, 17 Mayıs). Secret Agents of Capitalism. http://www.businessopportunities.biz/2004/05/17/secret-agents-of-capitalism/. Erişim Tarihi: 10 Ağustos 2016.

DURSUN, İ., \& KABADAYI, E.T. (2012). Tüketicilerin İkna Çabalarına Karş1 Gösterdikleri Direnç: Tutum Gücü, Tutum Yönü Ve Mesaj Gücünün Etkileri Üzerine Deneysel Bir Araştırma. Uluslararası Yönetim İktisat ve İsletme Dergisi, 8(16), 75-97.

GUPTA, P. B. \& LORD, K. R. (1998). Product Placement İn Movies: The Effect Of Prominence And Mode On Audience Recall. Journal Of Current Issues \& Research in Advertising, 20(1), 47-59. 
HAIR, J. F., BLACK, W., BABIN, B. Y. A., ANDERSON, R. E., ve TATHAM, R. L. (2009). Multivariate Data Analysis:A Global Perspective. (7th Ed.). NJ: Pearson Prentice Hall.

HOLBROOK, M. B. \& BATRA, R. (1987). Assessing The Role Of Emotions As Mediators Of Consumer Responses To Advertising. Journal Of Consumer Research, 14(3), 404-420.

HUANG, S. C. (2009). Deception İn Covertmarketing: From The Perspectives Of Law And Consumer Behavior. Marketing Theory And Applications, 40-48.

İSLAMOĞLU, A. H. ve ALNIAÇIK, Ü. (2013). Sosyal Bilimlerde Araştırma Yöntemleri. (Gözden Geçirilmiş ve Genişletilmiş 3. Bs.). İstanbul: Beta Yayınları

JURCA, M. A. (2010). Theforms Of Unconventional Advertising-A Theoretical Approach. Management \& Marketing-Craiova, (2), 323-333.

KAIKATI, A. M. \& KAIKATI, J. G. (2004). Stealthmarketing: How To Reach Consumers Surreptitiously. California Management Review. 46(4).

KIRBY, J. \& MARSDEN, P. (2006). Connected Marketing: The Viral, Buzz And Word Of Mouth Revolution. Oxford: Elseviereds

KLINE, R. B. (2011). Principles And Practice Of Structural Equation Modeling. Guilford Press.

KUHN, K. A. L., HUME, M., \& LOVE, A. (2010). Examining The Covert Nature Of Product Placement: Implications For Public Policy. Journal Of Promotion Management. 16(1-2), 59-79.

LEON, H. (2004, 5 Aralık). Secret Agents Of Capitalism.

http://www.metroactive.com/papers/metro/05.12.04/marketing-0420.html, Erişim Tarihi: 10 Ağustos 2016.

MACKENZIE, S. B., LUTZ, R. J. \& BELCH, G. E. (1986). The Role Of Attitude Toward The Ad As A Mediator Of Advertising Effectiveness: A Test Of Competing Explanations. Journal Of Marketing Research, 130-143.

MADDEN, T. J., ALLEN, C. T. \& TWIBLE, J. L. (1988). Attitude Toward The Ad: An Assessment Of Diverse Measurement Indices Under Different Processing Sets. Journal of Marketing Research, Vol. XXV, 242-252.

MARTIN, K. D. \& SMITH. N. C. (2008). Commercializing Social İnteraction: The Ethics Of Stealthmarketing. Journal Of Public Policy \& Marketing27.1, 45-56.

MILNE, G. R.,BAHL, S. \& ROHM, A. (2008). Toward A Framework For Assessing Covertmarketing Practices. Journal Of Public Policy \& Marketing, 27(1), 57-62.

NAKIP, M. (2006). Pazarlama Araştırmaları, Teknikler Ve (SPSS Destekli) Uygulamalar. (2.Bs.). Ankara: Seçkin.

ODABAŞI, Y. (2009). Postmodern Pazarlama. (3. Bs.). İstanbul: Medicat

ODABAŞI, Y. ve KILIÇER, T. (2010). Postmodern Dönemde Pazarlama. İ. Varinli Ve K. Çatı (Ed.). Güncel Pazarlama Yaklaşımlarından Seçmeler (Ss.31-55). Ankara: Detay Yayıncilik. 
OVLA, H. D. \& TAŞDELEN, B. (2012). Aykırı Değer Yönetimi. Mersin Üniversitesi Sağglk Bilimleri Dergisi, 5(3).

PETTY, R. D. \& ANDREWS, J. C. (2008). Covert Marketing Unmasked: A Legal And Regulatory Guide For Practices That Mask Marketing Messages. Journal Of Public Policy \& Marketing, 27(1), 7-18.

PRINGLE, H. (2007). Şöhret Satar. E. Yıldırım (Çev.). İstanbul: Mediacat Kitapları.

ROTFELD, H. J. (2008). The Stealth Influence Of Covert Marketing And Much Ado About What May Be Nothing. Journal Of Public Policy \& Marketing, 27(1), 63-68.

ROY, A. \& CHATTOPADHYAY, S. P. (2010). Stealthmarketing As A Strategy. Business Horizons, 53(1), 69-79.

RUTENBERG, J. (2001, 15 Temmuz). The Secret Agents Of Capitalism Are All Around Us. http://www.nytimes.com/2001/07/15/magazine/15PHENOMENON.html, Erişim Tarihi: 10 Ağustos 2016.

SCANLON, J. \& HEARN, B. (2006). Stealthmarketing: To Disclose Or Not To Disclose That is The (Legal) Question. Advertisingand Marketing Bulletin, Mcmillanbinchmendelshon.

SHIV, B., EDELL, J. A., \& PAYNE, J. W. (1997). Factors Affecting The İmpact Of Negatively And Positively Framed Ad Messages. Journal Of Consumer Research, 24(3), 285-294.

SILVERMAN, G. (2006). Ağızdan Ağıza Pazarlama: Dünyanın En Güçlü Pazarlama Yönteminin 28 Sırrı. (2. Bs.), E. Orfanlı (Çev.). İstanbul: Mediacat Kitapları.

SOLOMON, M. R (2003). Tüketici Krallığının Fethi. S.Çetinkaya (Çev.). İstanbul: Mediacat Kitaplar1.

SWANEPOEL, C., LYE, A., \& RUGIMBANA, R. (2009). Virally inspired: A Review Of The Theory Of Viral Stealth Marketing. Australasian Marketing Journal (AMJ),17(1), 9-15.

TAYLOR, J. (2003). Word Of Mouth is Where it is at. Brandweek, 44(22), 26.

YAĞCI, M. I., BISWAS, A., \& DUTTA, S. (2009). Effects Of Comparative Advertising Format On Consumer Responses: The Moderating Effects of Brand Image and Attribute Relevance. Journal Of Business Research, 62(8), 768-774.

WEI, M. L.,FISCHER, E., \& MAIN, K. J. (2008). An Examination Of The Effects Of Activating Persuasion Knowledge on Consumer Response to Brands Engaging in Covert Marketing. Journal Of Public Policy \& Marketing, 27(1), 34-44.

WEISBERG, A.,PFLEIGER, A., \&FRIEDBERG, J. (2007). Undercover Agency The Ethics Of Stealthmarketing. Confronting Information Ethics in the New Millennium, 92-106.

ZHANG, Y., \& BUDA, R. (1999). Moderating Effects Of Need For Cognition On Responses To Positively Versus Negatively Framed Advertising Messages. Journal of Advertising, 28(2), 1-15. 